\title{
Front Matter: Volume 10436
}

, "Front Matter: Volume 10436," Proc. SPIE 10436, High-Power Lasers: Technology and Systems, Platforms, and Effects, 104360R (21 November 2017); doi: 10.1117/12.2303738

SPIE. Event: SPIE Security + Defence, 2017, Warsaw, Poland 


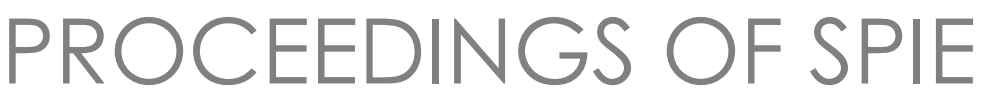

\title{
High-Power Lasers: Technology and Systems, Platforms, and Effects
}

\author{
Harro Ackermann \\ Willy L. Bohn \\ David H. Titterton \\ Editors
}

13-14 September 2017

Warsaw, Poland

Sponsored by

SPIE

Cooperating Organisations

CENSIS: Innovation Centre for Sensor \& Imaging Systems (United Kingdom)

Polish Technological Platform on Photonics (Poland)

MIRPHAB (France)

Photonics Society of Poland (Poland)

Cranfield University (United Kingdom)

Published by

SPIE 
The papers in this volume were part of the technical conference cited on the cover and title page. Papers were selected and subject to review by the editors and conference program committee. Some conference presentations may not be available for publication. Additional papers and presentation recordings may be available online in the SPIE Digital Library at SPIEDigitalLibrary.org.

The papers reflect the work and thoughts of the authors and are published herein as submitted. The publisher is not responsible for the validity of the information or for any outcomes resulting from reliance thereon.

Please use the following format to cite material from these proceedings:

Author(s), "Title of Paper," in High-Power Lasers: Technology and Systems, Platforms, and Effects, edited by Harro Ackermann, Willy L. Bohn, David H. Titterton, Proceedings of SPIE Vol. 10436 (SPIE, Bellingham, WA, 2017) Seven-digit Article CID Number.

ISSN: 0277-786X

ISSN: 1996-756X (electronic)

ISBN: 9781510613362

ISBN: 9781510613379 (electronic)

Published by

SPIE

P.O. Box 10, Bellingham, Washington 98227-0010 USA

Telephone +1 3606763290 (Pacific Time) · Fax +1 3606471445

SPIE.org

Copyright @ 2017 , Society of Photo-Optical Instrumentation Engineers.

Copying of material in this book for internal or personal use, or for the internal or personal use of specific clients, beyond the fair use provisions granted by the U.S. Copyright Law is authorized by SPIE subject to payment of copying fees. The Transactional Reporting Service base fee for this volume is $\$ 18.00$ per article (or portion thereof), which should be paid directly to the Copyright Clearance Center (CCC), 222 Rosewood Drive, Danvers, MA 01923. Payment may also be made electronically through CCC Online at copyright.com. Other copying for republication, resale, advertising or promotion, or any form of systematic or multiple reproduction of any material in this book is prohibited except with permission in writing from the publisher. The CCC fee code is 0277 $786 \times / 17 / \$ 18.00$.

Printed in the United States of America.

Publication of record for individual papers is online in the SPIE Digital Library.

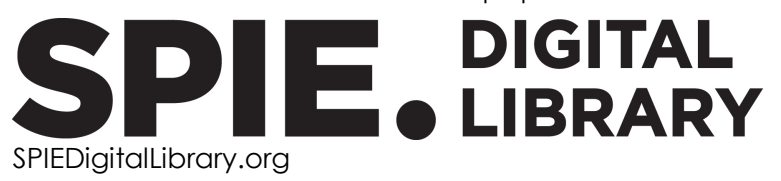

Paper Numbering: Proceedings of SPIE follow an e-First publication model. A unique citation identifier (CID) number is assigned to each article at the time of publication. Utilization of CIDs allows articles to be fully citable as soon as they are published online, and connects the same identifier to all online and print versions of the publication. SPIE uses a seven-digit CID article numbering system structured as follows:

- The first five digits correspond to the SPIE volume number.

- The last two digits indicate publication order within the volume using a Base 36 numbering system employing both numerals and letters. These two-number sets start with $00,01,02,03$, 04, 05, 06, 07, 08, 09, 0A, OB ... 0Z, followed by 10-1Z, 20-2Z, etc. The CID Number appears on each page of the manuscript. 


\title{
Contents
}

\author{
$\checkmark \quad$ Authors \\ vii Conference Committee \\ ix Introduction
}

LASER ARCHITECTURES FOR POWER SCALING AND PLATFORMS

1043602 Analysis of optical scheme for medium-range directed energy laser weapon system (Invited Paper) [10436-1]

1043605 Tunable line width all solid state double spectral line sodium beacon laser [10436-5]

\section{DIODE PUMPED ALKALI LASERS}

10436 OB New results for temperature rise in gain medium of operating DPAL causing its degradation (Invited Paper) [10436-12]

10436 OC Experimental studies and modeling of static Cs DPALs: dependence of the power and beam shape on different parameters (Invited Paper) [10436-13]

10436 OD Scaling up and controlling beam quality of flowing-gas diode pumped potassium laser with different pumping geometries: 3D CFD modeling (Best Student Paper) [10436-14]

10436 OE Modeling of multi-transversal mode lasing in static alkali vapor lasers [10436-15]

10436 OF Three-dimensional simulation of beam propagation and heat transfer in static gas Cs DPALs using wave optics and fluid dynamics models [10436-16]

\section{LASER INTERACTION, EFFECTS AND COMPONENTS}

10436 OG Standoff spectroscopic interrogation of samples irradiated by high energy lasers [10436-17]

$10436 \mathrm{OH}$ Investigations of high power laser beam interaction with composite materials by means of digital image correlation and thermography [10436-19]

10436 ol High-efficiency mid-infrared optical parametric amplifier with approximate uniform rectangular pump distribution [10436-4] 
POSTER SESSION

10436 OM High-peak power, athermal Nd:YAG transmitter [10436-26]

10436 ON Experimental investigation of the photodarkening induced core laser leakage in a $3 \mathrm{~kW}$ co-pumping fiber amplifier [10436-10]

1043600 Optimization for the fiber laser source through its temporal and spectral characteristics [10436-11] 


\section{Authors}

Numbers in the index correspond to the last two digits of the seven-digit citation identifier (CID) article numbering system used in Proceedings of SPIE. The first five digits reflect the volume number. Base 36 numbering is employed for the last two digits and indicates the order of articles within the volume. Numbers start with 00, 01, 02, 03, 04, 05, 06, 07, 08, 09, OA, OB...0Z, followed by 10-1Z, 20-2Z, etc.

Auslender, llya, OC, OE

Barmashenko, Boris D., OC, OD, OE, OF

Chen, Jinbao, ON

Daigle, Jean-François, $0 G$

Fan, Guobin, 05

Gao, Jianrong, 01

Gong, Shenggang, 05

Gorajek, Łukasz F., 02, 0M

Gu, Jingliang, 05

Jabczyński, Jan K., 02, 0M

Jiang, Zongfu, ON, $0 \mathrm{O}$

Kaśków, Mateusz, 02, 0M

Knize, R. J., OB

Kong, Lingchao, ON

Kopczyński, Krzyszłof, 02

Kujawinska, Malgorzata, $\mathrm{OH}$

Kustron, Kamila, $\mathrm{OH}$

Leng, Jinyong, ON

Li, Miao, ON

Li, Tao, 05

Liu, Wei, 00

Lu, Yanhua, 05

Luo, Xingwang, 0

Ma, Pengfei, 00

Malesa, Marcin, $\mathrm{OH}$

Nie, Zan, 01

Peng, Jue, 0 I

Peng, Yuefeng, 0 I

Pudo, Dominik, OG

Puzewicz, Zbigniew, OM

Ren, Huaijin, 05

Rosenwaks, Salman, OC, OD, OE, OF

Rotondaro, M. D., OB

Sadot, Oren, OD

Shaffer, M. K., OB

Siedlecki, Krzysztof, $\mathrm{OH}$

Théberge, Francis, OG

Waichman, Karol, OD, OF

Wan, Min, 05

Wang, Xiaolin, ON

Wei, Bin, 05

Wei, Xingbin, 01

$\mathrm{Xu}$, Xiafei, 05

$\mathrm{Xu}, \mathrm{Xiaojun}, \mathrm{ON}$

Yacoby, Eyal, OC, OD

Yuan, Liao, 05

Zendzian, Waldemar, OM

Zhang, Lei, 05

Zhdanov, B. V., OB
Zhou, Pu, ON, 00

Zhou, Tangjian, 0 I 
Proc. of SPIE Vol. 10436 104360R-6

Downloaded From: https://www.spiedigitallibrary.org/conference-proceedings-of-spie on 25 Apr 2023 Terms of Use: https://www.spiedigitallibrary.org/terms-of-use 


\title{
Conference Committee
}

\author{
Symposium Chair \\ Ric Schleijpen, TNO Defence, Security and Safety \\ (Netherlands) \\ Symposium Co-Chairs \\ Karin Stein, Fraunhofer Institute of Optronics, System Technologies \\ and Image Exploitation IOSB (Germany) \\ Jan K. Jabczyński, Military University of Technology (Poland) \\ Conference Chairs \\ Harro Ackermann, High Energy Laser Joint Technology Office \\ (United States) \\ Willy L. Bohn, BohnLaser Consult (Germany) \\ David H. Titterton, UK Defence Academy (United Kingdom) \\ Conference Programme Committee \\ Pierre Bourdon, ONERA (France) \\ Martin C. Richardson, CREOL, The College of Optics and Photonics, \\ University of Central Florida (United States) \\ Jasbinder S. Sanghera, U.S. Naval Research Laboratory \\ (United States)
}

\section{Session Chairs}

1 Laser Architectures for Power Scaling and Platforms

Willy L. Bohn, BohnLaser Consult (Germany)

2 Fiber Lasers and Beam Shaping

David H. Titterton, Defence Science and Technology Laboratory (United Kingdom)

3 Diode Pumped Alkali Lasers

Jasbinder S. Sanghera, U.S. Naval Research Laboratory

(United States)

4 Laser Interaction, Effects and Components

Willy L. Bohn, BohnLaser Consult (Germany) 
Proc. of SPIE Vol. 10436 104360R-8

Downloaded From: https://www.spiedigitallibrary.org/conference-proceedings-of-spie on 25 Apr 2023 Terms of Use: https://www.spiedigitallibrary.org/terms-of-use 


\section{Introduction}

This was the sixth high-power laser conference, which had an excellent attendance throughout the four sessions despite some last-minute cancellations. However a fairly full programme was maintained through Prof Bohn delivering one key-note address on behalf of the 'JTO' presenter, who was unable to travel. In general, the quality of the papers was high, with some excellent innovative ideas presented. In addition, some intensive discussions and exchange of ideas took place among the experts in all sessions of the conference. It provided an excellent forum for attendees, specialists and newcomers, especially in the areas of laserdevice demonstration and evaluation of laser-based systems, along with analysis of laser-induced effects.

In the first session a key-note presentation was given by Dr Jabczynski from the Wojskowa Academy (Poland) concerning the analysis of a medium-range directed-energy laser system The contributing papers from this session described a multi-terrawatt OPCPA system and a tuneable linewidth all solid-state guide-star (sodium line) device.

The second session (Fiber Lasers and Beam Scaling) was a valuable session with all the scheduled papers delivered. The two invited papers described recent progress with scaling of fibre lasers and a route to 'eye-safer' silica fibre systems through exploitation of nano-particles enabling high-power emission from erbium transitions. The two contributing papers described progress with the development of mid-infrared fibre lasers for remote sensing through super-continuum generation and the demonstration of an all-glass micro-structured fibre cladding light-stripper. The latter device had been developed for use with kilowatt-class laser systems.

The third session covered advanced gas-laser developments, and in particular, advances with diode-pumped alkali lasers (DPALs). Dr Zhdanov's invited paper described studies investigating the degradation mechanisms in DPALs, supported by some recent results. A second invited paper described experimental and theoretical studies with a caesium static cell device. The three contributing papers were from Ben-Gurion University of the Negev concerning supporting simulations of lasing events in static and flowing alkali-vapour cells.

The final session covered presentations on Laser Interaction, Effects and Components with three contributory papers. These papers covered analysis of the spectral emission from targets when illuminated with an intense laser beam, the interaction effects on composite materials and the development of a mid-wave infrared, high-power device. The first two papers in this session stimulated some very interesting discussion with regard to standoff target identification and discrimination during high energy laser irradiation.

All of the sessions were well attended, and as indicated above, the discussions were certainly very valuable. These discussions provided an invaluable insight into the way that the high-power source technology and systems are evolving and being applied to meet military capability requirements.

The current fiscal constraints and failure of presenters to attend had an adverse effect on the conference programme. Consequently, there was an impact on the content of the programme; however, despite this impediment, this was still a viable and most valuable conference.

Harro Ackermann
Willy L. Bohn
David H Titterton 
Proc. of SPIE Vol. 10436 104360R-10

Downloaded From: https://www.spiedigitallibrary.org/conference-proceedings-of-spie on 25 Apr 2023 Terms of Use: https://www.spiedigitallibrary.org/terms-of-use 